\title{
Moving towards virtuousness in organization: An analysis of factors affecting virtuous organizations
}

\author{
Majid Zamahani, Ali Akbar Ahmadi, Mohammad Ali Sarlak and Hamideh Shekari*
}

Management Department, Payame Noor University, Tehran, I. R. of Iran

\begin{tabular}{|c|c|}
\hline A R T I C L E I N F O & A B S T R A T \\
\hline $\begin{array}{l}\text { Article history: } \\
\text { Received July } 15,2012 \\
\text { Received in Revised form } \\
\text { August, } 27,2012 \\
\text { Accepted } 19 \text { September } 2012 \\
\text { Available online } \\
\text { September } 222012 \\
\text { Keywords: } \\
\text { Virtues } \\
\text { Virtuous Organization } \\
\text { Delphi Study } \\
\text { Exploratory Factor Analysis }\end{array}$ & $\begin{array}{l}\text { For years, there has been growing interest on virtues, especially in various organizations and } \\
\text { progressive companies are exploring their impacts in generating new, holistic, healthy, and } \\
\text { human work environments. Many firms are trying to become more sensitive to the requirements } \\
\text { of the community and virtuous concerns such as caring, compassion, integrity and wisdom, and } \\
\text { less interested in ideas such as efficiency, profitability and competitive advantage. In other } \\
\text { words, most firms are going towards virtuous firms. The primary objective of this work is to } \\
\text { detect the drivers and principal components of a virtuous firm to put virtues into practice. The } \\
\text { study consists of two parts. In the first part, a Delphi study among the informed individuals is } \\
\text { conducted and request them to detect the most effective drivers of virtuous firm, while in the } \\
\text { second part, we do an exploratory factor analysis to detect the principal factors influencing } \\
\text { virtuous organization. The data implemented in this phase include questionnaire responses. } \\
\text { The survey distributes } 750 \text { questionnaires and collects } 574 \text { valid responses. The factor analysis } \\
\text { empirically grouped the drivers of virtuous organization into five factors including Leadership, } \\
\text { Human Resource, Organizational Culture, Structure and Processes and Care for Community. } \\
\text { These five factors describe approximately } 81.305 \% \text { of the total variance. Finally, we ranked the } \\
\text { principal factors extracted from factor analysis. }\end{array}$ \\
\hline
\end{tabular}

\section{Introduction}

Virtues and virtuous organization are two terms, which have been neglected in organizational literature and for many years (Rego et al., 2011). Virtues have been conventionally viewed as relativistic, culture-specific, and are more related to social conservatism, religious or moral dogmatism, and scientific irrelevance. There has been little attention to virtues, especially in organizations, but it has remained mostly with no criticism among different managers faced with economic pressures and stakeholder demands (Manz et al., 2008). However, during the past few years, many people have assumed that cultivating virtues, both at the individual and organizational

* Corresponding author. Tel: +989133565884

E-mail addresses: 1_shekari60@yahoo.com (L. Shekari, PhD student) 
levels, could improve individual betterment and organizational performance (Cameron, 2010; Wright \& Goodstein, 2007).

They emphasized that virtue requires to be added to the business and management research agenda (Rego et al., 2011). In cases of turbulent change, virtuousness serves both as a fixed point, a benchmark for making sense of ambiguity, and as a primary source of resilience, preventing system from any damages. Therefore, we propose to develop the literature on virtuous organization and determine the drivers and principal factors of a virtuous organization to put virtues into practice in organizations.

\section{Literature Review}

\subsection{Virtue and Virtuousness}

The ideas of virtue and virtuousness can be defined in different ways in the literature:

- Virtue refers to singular attributes, which represent moral excellence but a virtue is not a product of social convention, it is, in fact, a basic element of the human condition (Cameron, 2011).

- Virtues are the characters traits, which make it possible for one to engage efficiently in a practice by looking for excel in achieving its internal goods while keeping the external excellence of its organizational setting in a position of lesser importance (Cooper, 1987).

- Virtue can be classified as an attribute of personal character, and it possesses cognitive, affective, volitional, and behavioral characteristics (Peterson, 2003).

- A virtue is a trait of character or intellect, which is morally laudable (Flynn, 2008).

- Virtues can be described as the qualities, which make anything a good thing of such kind (Schudt, 2000).

- Beauchamp \& Childress provide one of the most popular definitions of virtue (1994, p. 63): 'a virtue is a trait of character that is socially valued and a moral virtue is a trait that is morally valued'.

- Virtuousness is described as the best of the human condition, the most ennobling attitude and outcomes and the highest aspirations of human beings (Comte-Sponville, 2001).

- Virtuousness means the pursuit of the highest aspirations in the human condition (Bright et al., 2006; Rego et al., 2011).

- Virtuousness is the internalization of moral rules, which produces social harmony (Manz et al., 2008).

Virtuousness is related to what individuals and organizations aspire to be when they are at their very best. Virtuousness can be described in connection with meaningful life purpose, the ennoblement of human beings, personal flourishing, which leads to health, happiness and resilience in suffering. It produces "moral muscle," willpower, or stamina in the face of challenges (Cameron et al., 2004).

\subsection{Organizational Virtuousness}

Organizations impact the conduct of their members, including ethical aspects of their conduct (Trevino \& Weaver, 2003). The moral climate and context and social interactions not only communicate moral norms but also they are the process forming the characters of people in the organizations. The good society and the moral of the individuals' characteristics in the society are interactive impacts. Virtues incorporate a linkage between the levels of the individual and his society, allowing one to fit within the social organization. Virtues are necessary moral attributes of individuals, which represent the excellencies and the social organization requirements. Ethics is more organizational issue whereas an organization of virtuous people is not enough to guarantee virtuous organizational decisions, and whereas organizational structures are instrumentally necessary (whetstone, 2005). 
Contributing the quality of virtuousness to a firm specifies that the organization is able to support virtuous activities on the part of its members. Virtuousness in organizations, therefore, is associated with transcendent and to elevate behavior of the firm's members. Organizational virtuousness is individuals' actions, collective or cultural attributes, or processes, which enable dissemination of virtuousness in any firm. In addition, no single indicator can compute the multiple indicators of virtuousness and there are three key definitions attributes associated with virtuousness, which help explain its relationships in organizational studies. Virtuousness is related to moral goodness and represents what is good and worthy of cultivation. Virtuousness is also related human beings with individual flourishing. Finally, virtuousness is specified by social betterment, which extends beyond mere self-interested benefit (Cameron et al., 2004).

Virtuousness in organizations is more associated with the behavior of individuals in organizational settings (Seligman \& Csikszentmihalyi, 2000; Snyder \& Lopez, 2002). Organizational virtuousness is associated with organizational contexts where the "good" habits, desires and actions are practiced and disseminated both at the individual and collective levels (Cameron et al., 2004; Rego et al., 2011; Cameron, 2003). Organizational virtuousness is associated with the attributes characterizing the best of a human resource (Nepean, 2007) and moral value and organizational virtue are more or less correlated (Ahmed \& Machold, 2004).

\subsection{Characteristics of a Virtuous organization}

It is always useful to compare the performance of organizations with their members and to provide people with meaningful work and rewards, organizations often require being successful, which needs to be successful. The main problem is to design firms, which perform at high levels and make sure that they are motivated to handle possible challenges and virtuous organization is a framework to handle such challenges (Lawler, 2004).

Virtuous organization needs to possess attributes and to demonstrate behaviors, which should possess more than a strong values-based culture (Nepean, 2007). Virtuous organizations develop different principles, which inspire good behavior (Magill \& prybil, 2001). To reach virtuousness, firms need to develop some necessary characteristics and there are literally many ways to do it (Paine, 2003) such as acting with integrity, honor commitments, strive for excellence, having more fun through work, etc. According to Manz et al. (2008), a virtuous organization needs to have the following eight attributes including responsibility of purpose and constituencies, honestly, reliability, fairness, integrity, respect to other individuals and properties.

According to Chappell (1993), a virtuous organization must have a statement of beliefs, which includes belief in both human beings and nature have inherent worth and deserve respect, belief in products that are safe, effective and made of natural ingredients, belief that our company and our products are unique and worthwhile, people are responsible to cultivate the best relationships with others, belief in providing employees with a safe and fulfilling working environment and finally, belief that the firm is financially successful while behaving in a socially responsible and environmentally sensitive manner.

According to Friedman and Friedman (2009), there are several critical success factors of a virtuous organization such as local community, respect for employees, hiring the disabled employees, diversity in the workplace, ethics and integrity, servant-leadership, customer satisfaction, environment, corporate philanthropy and mission statement. Friedman et al. (2008) specified different principles for virtuous organization including avoiding harming others, respect others' rights, prevent any cheating, be faithful to promises, obey the law, prevent harm to others, help those who need, be fair and reinforce these imperatives in others.

According to Rego et al. (2011), to build virtuous climates, managers must care about how employees perceive the organization and its managers, paying attention to a number of aspects and employees 
must be optimistic towards challenges, difficulties and opportunities, be respectful and trustful on acting, etc.

\section{Methodology}

The primary objective of this paper is to determine the drivers of virtuous organization to put virtues into practice in universities located in province of Yazd, Iran. The procedure we propose is to reach the above-stated research aim consists of two steps. In the first step, we conduct a Delphi study among the informed individuals, asking them to identify the most effective drivers of virtuous organization.

In the second Step, we perform a factor analysis to validate the measurement scales for virtuous organization and to identify its principal factors. The data used in this phase consist of questionnaire responses from employees in three different Universities in Yazd, namely Islamic Azad University, Payam e Noor University and Yazd University. A total of 750 questionnaires were sent out, 250 to each university and a total of 574 valid responses were received.

\section{Delphi Study}

To find drivers of virtuous organization, Delphi method was implemented. Although we could select the critical variables through the traditional statistical analysis methods, Delphi method was used as a stronger methodology.

Delphi is a method of popular survey technique, which brings consensus of opinions among a set of experts by keeping the unanimity among them. During the past few years, various applications of Delphi have been evolved, worldwide. The application of Delphi process includes planning, decision making, forecasting, impact assessment, etc. Delphi process has also been implemented for different purposes like setting 'goals', finding 'problems', forecasting, developing system. The proposed study of this paper uses 53 measurement items developed on the basis of the literature review:

1. Hiring the Disabled (Friedman \& Friedman, 2009)

2. Diversity in the Workplace (Friedman \& Friedman, 2009)

3. Respect and caring for Employees (Friedman et al., 2008; Grimley, 2008; Friedman \& Friedman, 2009)

4. Promoting Ethics (Whetstone, 2005; Friedman \& Friedman, 2009; Sosik et al., 2011)

5. Concerning about the Local suppliers (Saylorr, 2005; Grimley, 2008; Friedman \& Friedman, 2009)

6. Concerning about the Environment and the community (Paine, 2003; Friedman \& Friedman, 2009; Friedman et al., 2008)

7. Considering virtuousness in organization's mission statement (Whetstone, 2005; Friedman \& Friedman, 2009)

8. Considering virtuousness in organization's mission statement as an end not as a means (Barge \& Oliver, 2003; Cameron, 2011; Caza \& Carroll, 2012)

9. Corporate Philanthropy (Friedman \& Friedman, 2009)

10. Allotting a special budget to help the homeless find job and housing (Friedman et al., 2008)

11. Not only concentrating on profit maximization (Ip, 2002)

12. Obeying the law (Friedman et al., 2008; Grimley, 2008)

13. Taking care of customers (Customer Satisfaction) (Friedman \& Friedman, 2009; Friedman et al., 2008; Grimley, 2008)

14. Providing employees with a safe work environment (Paine, 2003; Friedman et al., 2008)

15. Providing employees with an opportunity to grow and learn (Friedman et al., 2008)

16. Behaving in a socially responsible and environmentally sensitive manner (Friedman et al., 2008) 
17. Honour commitments to customers, teammates, communities, owners, suppliers and partners (Keep promises and contracts) (Paine, 2003; Manz et al., 2008)

18. Strive for excellence (Paine, 2003)

19. Providing employees with a fulfilling work environment (meaningful and joyful work) (Collins, 2000; Paine, 2003)

20. Avoiding harming others (Friedman et al., 2008)

21. Respect the rights of others (Friedman et al., 2008)

22. Help those in need (Saylorr, 2005; Friedman et al., 2008)

23. Being fair (Lawler, 2004; Friedman et al., 2008)

24. Servant leadership (Whetstone, 2005; Maak \& Pless, 2006; Pless, 2007; Cameron, 2011; Friedman \& Friedman, 2009)

25. Responsible leadership (Maak \& Pless, 2006; Pless, 2007; Cameron, 2011)

26. Paying attention to thinking and knowledge acquisition (Lawler, 2004)

27. Employees autonomy and self management (Collins, 2000)

28. Human resource diversity at workplace (Collins, 2000; Paine, 2003)

29. Empowering employees (Paine, 2003; Friedman et al., 2008)

30. Paying attention to employee's development more than their training (Manz et al., 2008; Friedman et al., 2008)

31. Reciprocal relationship and respect between managers and employees (Rego et al., 2011)

32. Organization's culture (Manz et al., 2008; Cameron, 2010)

33. An optimistic perspective toward challenges, difficulties, and opportunities (Rego et al., 2011)

34. A high level of honesty and integrity at every organizational level (Not to cheat or tell lie) (Paine, 2003; Rego et al., 2011)

35. Interpersonal relationships characterized by caring and compassion (Rego et al., 2011)

36 . The combination of high standards of performance with a culture of forgiveness and learning from mistakes (Rego et al., 2011)

37. Employees perception of virtuousness in organization (Rego et al., 2011)

38. Employee's self-control (Lawler, 2004)

39. Employee's stability in difficulties and crises (Lawler, 2004)

40. Faithful employees (Lawler, 2004)

41. Courageous employees (Lawler, 2004)

42. Matching managers conduct and words (Lawler, 2004)

43. Vesting authority to employees along with supporting from managers (Magill \& Prybil, 2001)

44. Existence of ethical standards for employee's and manager's behavior (Whetstone, 2005)

45. Decreasing the hierarchy (Cooper, 1987; Cameron, 2011)

46. Decreasing the bureaucracy (Cooper, 1987)

47. Going beyond ethics (Manz et al., 2008; Hannah \& Avolio, 2011)

48. Down to up hierarchy (Dutton et al., 2002)

49. Optimal use of environmental resources (Magill \& prybil, 2001)

50. High quality relationship with employees (Friedman et al., 2008)

51. Considering virtues in organizational policies and processes (Whetstone, 2005; Cameron, 2010)

52. Existence of transparency in organization (Shared information) (Friedman et al., 2008)

53. Penetrating virtues in employee's feelings, thinking and actions (Rego et al., 2011)

Based on these items, the first round of questionnaire was designed. Five-point Likert scales, ranging from five, "very important" to one, "not very important" were used for scoring of each indicator in the questionnaire. A panel of 40 members from universities and research institutions was formed. The Results of Delphi study are shown in Table 1 and Table 2. 


\section{Table 1}

Results of Delphi study

\begin{tabular}{llllllll}
\hline Round & $\begin{array}{l}\text { No. of } \\
\text { distributed } \\
\text { questionnaires }\end{array}$ & $\begin{array}{l}\text { No. of valid } \\
\text { returned } \\
\text { questionnaires }\end{array}$ & $\begin{array}{l}\text { Response } \\
\text { Rate }\end{array}$ & $\begin{array}{l}\text { Kendall's } \\
\text { W }\end{array}$ & $\begin{array}{l}\text { Chi- } \\
\text { square }\end{array}$ & df & $\begin{array}{l}\text { Asymp. } \\
\text { Sig. }\end{array}$ \\
\hline 1 & 40 & 30 & 0.75 & .341 & 307.099 & 60 & .000 \\
2 & 30 & 26 & 0.87 & .426 & 275.222 & 59 & .000 \\
3 & 26 & 24 & 0.96 & .783 & 250.887 & 56 & .102 \\
\hline
\end{tabular}

Table 2

Removal or addition of items in the different rounds of Delphi study

\begin{tabular}{|c|c|c|}
\hline Round & Removals & Additions \\
\hline 1 & $\begin{array}{l}\text { - Providing employees with a safe } \\
\text { work environment } \\
\text { - Decreasing the bureaucracy }\end{array}$ & $\begin{array}{l}\text { - Parentism and participatory management } \\
\text { - Spiritual leadership } \\
\text { - Direct training } \\
\text { - Organizational citizenship behaviors } \\
\text { - Considering virtues in the culture of community } \\
\text { - Respect the social laws } \\
\text { - Respect the social values } \\
\text { - Managers support in all affairs especially in } \\
\text { difficult situations and crises } \\
\text { - Considering employee's competencies } \\
\text { - Employee's readiness from the point of view of } \\
\text { individual characteristics, motives, internal } \\
\text { tendency,... } \\
\text { - Decreasing formalization and standardization }\end{array}$ \\
\hline 2 & $\begin{array}{l}\text { - Parentism and participatory } \\
\text { management } \\
\text { - Direct training } \\
\text { - Decreasing formalization and } \\
\text { standardization } \\
\text { - meaningful and joyful work } \\
\text { - Employees autonomy and self } \\
\text { management }\end{array}$ & $\begin{array}{l}\text { - Indirect training through storytelling approach } \\
\text { - Employees as competitive advantages for } \\
\text { organization }\end{array}$ \\
\hline 3 & ----- & ----- \\
\hline
\end{tabular}

Since the Kendall's W of the third round is 0.783 and more than 0.5 , so we stop the Delphi study. The final drivers of virtuous organization and their rank according to expert's responses and Kendall's test can be seen in Table 3 .

\section{Factor Analysis and Data Analysis}

Based on the fifty-eight items identified in the previous section, the questionnaire for conducting step two was designed. Five-point Likert scales were used for scoring of each indicator in the questionnaire. The data used in this phase consist of questionnaire responses from employees in three various universities in Yazd, namely Islamic Azad University, Payam e Noor University and Yazd University. A total of 750 questionnaires were sent out, 250 to each university. A total of 574 valid responses were received. An exploratory factor analysis was conducted to derive groupings of the drivers of virtuous organization from the survey data. The results of factor analysis are shown in Fig. 1 and Table 4 to Table 7. Based on Table 4, The Kaiser criterion is 0.899 and the Sig. of the test is less than 0.05 . These tests confirm that the factor analysis of the 58 items in this study is generally appropriate. This shows that the degree of common variance among the items is quite high, therefore factor analysis can be conducted. 
Table 3

Ranking the drivers of virtuous organization

Measurement Items

Mean rank

based on

Rank

Kendall's test

\begin{tabular}{|c|c|c|c|}
\hline $\mathrm{x}_{1}$ & Faithful employees & 41.31 & 1 \\
\hline $\mathrm{x}_{2}$ & Corporate Philanthropy & 41.29 & 2 \\
\hline $\mathrm{x}_{3}$ & Promoting Ethics & 39.94 & 3 \\
\hline $\mathrm{x}_{4}$ & Servant leadership & 39.33 & 4 \\
\hline $\mathrm{x}_{5}$ & High quality relationship with employees & 39.31 & 5 \\
\hline $\mathrm{x}_{6}$ & $\begin{array}{l}\text { Employee's readiness from the point of view of individual characteristics, motives, internal } \\
\text { tendency,... }\end{array}$ & 39.02 & 6 \\
\hline $\mathrm{x}_{7}$ & Employees as competitive advantages for organization & 38.08 & 7 \\
\hline $\mathrm{x}_{8}$ & Considering virtuousness in organization's mission statement & 38.04 & 8 \\
\hline $\mathrm{x}_{9}$ & Respect the social laws & 37.98 & 9 \\
\hline $\mathrm{x}_{10}$ & Not only concentrating on profit maximization & 37.08 & 10 \\
\hline $\mathrm{x}_{11}$ & $\begin{array}{l}\text { Honor commitments to customers, teammates, communities, owners, suppliers and partners (Keep } \\
\text { promises and contracts) }\end{array}$ & 36.98 & 11 \\
\hline $\mathrm{x}_{12}$ & Going beyond ethics & 36.71 & 12 \\
\hline$x_{13}$ & Avoiding harming others & 36.17 & 13 \\
\hline $\mathrm{x}_{14}$ & Spiritual leadership & 35.25 & 14 \\
\hline $\mathrm{x}_{15}$ & Respecting the rights of others & 35.25 & 15 \\
\hline $\mathrm{x}_{16}$ & Being fair & 35.25 & 16 \\
\hline $\mathrm{x}_{17}$ & Obeying the law & 35.25 & 17 \\
\hline $\mathrm{x}_{18}$ & Respect the social values & 33.83 & 18 \\
\hline $\mathrm{x}_{19}$ & Allotting a special budget to help the homeless find job and housing & 33.56 & 19 \\
\hline $\mathrm{x}_{20}$ & Considering virtuousness in organization's mission statement as an end not as a means & 33.35 & 20 \\
\hline $\mathrm{x}_{21}$ & A high level of honesty and integrity at every organizational level (Not to cheat or tell lie) & 32.29 & 21 \\
\hline $\mathrm{x}_{22}$ & Interpersonal relationships characterized by caring and compassion & 32.29 & 22 \\
\hline $\mathrm{x}_{23}$ & Hiring the Disabled & 32.29 & 23 \\
\hline $\mathrm{x}_{24}$ & Considering virtues in the culture of community & 32.29 & 24 \\
\hline $\mathrm{x}_{25}$ & Employees perception of virtuousness in organization & 30.83 & 25 \\
\hline $\mathrm{x}_{26}$ & Respect and caring for Employees & 30.75 & 26 \\
\hline $\mathrm{x}_{27}$ & Matching managers conduct and words & 30.75 & 27 \\
\hline $\mathrm{x}_{28}$ & Existence of ethical standards for employee's and manager's behavior & 30.75 & 28 \\
\hline $\mathrm{x}_{29}$ & Existence of transparency in organization (Shared information) & 30.75 & 29 \\
\hline $\mathrm{x}_{30}$ & Strive for excellence & 30.75 & 30 \\
\hline $\mathrm{x}_{31}$ & Organizational citizenship behaviors & 30.75 & 31 \\
\hline $\mathrm{x}_{32}$ & Indirect training through storytelling approach & 27.79 & 32 \\
\hline $\mathrm{x}_{33}$ & Reciprocal relationship and respect between managers and employees & 27.79 & 33 \\
\hline $\mathrm{x}_{34}$ & Human resource diversity at workplace & 27.79 & 34 \\
\hline $\mathrm{x}_{35}$ & Help those in need & 27.79 & 35 \\
\hline $\mathrm{x}_{36}$ & Considering virtues in organizational policies and processes & 27.79 & 36 \\
\hline$x_{37}$ & Concerning about the Environment and the community & 27.79 & 37 \\
\hline$x_{38}$ & Optimal use of environmental resources & 27.79 & 38 \\
\hline$x_{39}$ & Concerning about the Local suppliers & 27.08 & 39 \\
\hline $\mathrm{x}_{40}$ & Paying attention to employee's development more than their training & 27.08 & 40 \\
\hline $\mathrm{x}_{41}$ & Considering employee's competencies & 27.08 & 41 \\
\hline $\mathrm{x}_{42}$ & Penetrating virtues in employee's feelings, thinking and actions & 24.13 & 42 \\
\hline$x^{43}$ & Responsible leadership & 24.13 & 43 \\
\hline $\mathrm{x}_{44}$ & Diversity in the Workplace & 24.13 & 44 \\
\hline $\mathrm{x}_{45}$ & Behaving in a socially responsible and environmentally sensitive manner & 21.77 & 45 \\
\hline $\mathrm{x}_{46}$ & Managers support in all affairs especially in difficult situations and crises & 19.85 & 46 \\
\hline $\mathrm{x}_{47}$ & Employee's stability in difficulties and crises & 18.65 & 47 \\
\hline $\mathrm{x}_{48}$ & Providing employees with an opportunity to grow and learn & 17.63 & 48 \\
\hline $\mathrm{x}_{49}$ & An optimistic perspective toward challenges, difficulties, and opportunities & 16.90 & 49 \\
\hline $\mathrm{x}_{50}$ & Employee's self-control & 16.73 & 50 \\
\hline $\mathrm{x}_{51}$ & Empowering employees & 16.73 & 51 \\
\hline $\mathrm{x}_{52}$ & Paying attention to thinking and knowledge acquisition & 16.73 & 52 \\
\hline $\mathrm{x}_{53}$ & Decreasing the hierarchy & 16.27 & 53 \\
\hline $\mathrm{x}_{54}$ & $\begin{array}{l}\text { The combination of high standards of performance with a culture of forgiveness and learning from } \\
\text { mistakes }\end{array}$ & 14.98 & 54 \\
\hline $\mathrm{x}_{55}$ & Vesting authority to employees along with supporting from managers & 14.98 & 55 \\
\hline $\mathrm{x}_{56}$ & Down to up hierarchy & 13.06 & 56 \\
\hline $\mathrm{x}_{57}$ & Taking care of customers (Customer Satisfaction) & 13.06 & 57 \\
\hline $\mathrm{x}_{58}$ & Courageous employees & 13.02 & 58 \\
\hline
\end{tabular}




\section{Table 4}

Results of factor analysis: KMO and Bartlett's Test

\begin{tabular}{ll|c}
\hline Kaiser-Meyer-Olkin Measure of Sampling Adequacy. & 0.899 \\
\hline Bartlett's Test of Sphericity & Approx. Chi-Square & 28389.11 \\
& df & 1653 \\
Sig. & 0.000 \\
\hline
\end{tabular}

Basically, there are two methods to decide the number of factors i.e. the Scree Plot (Fig. 1) and the Total Variance Explained (Table 5). Based on these two outputs, there must be five common factors with common issues. Based on the Scree plot below, the 'elbow' starts at component number 5. We should have 5 common factors that can be extracted from the data.

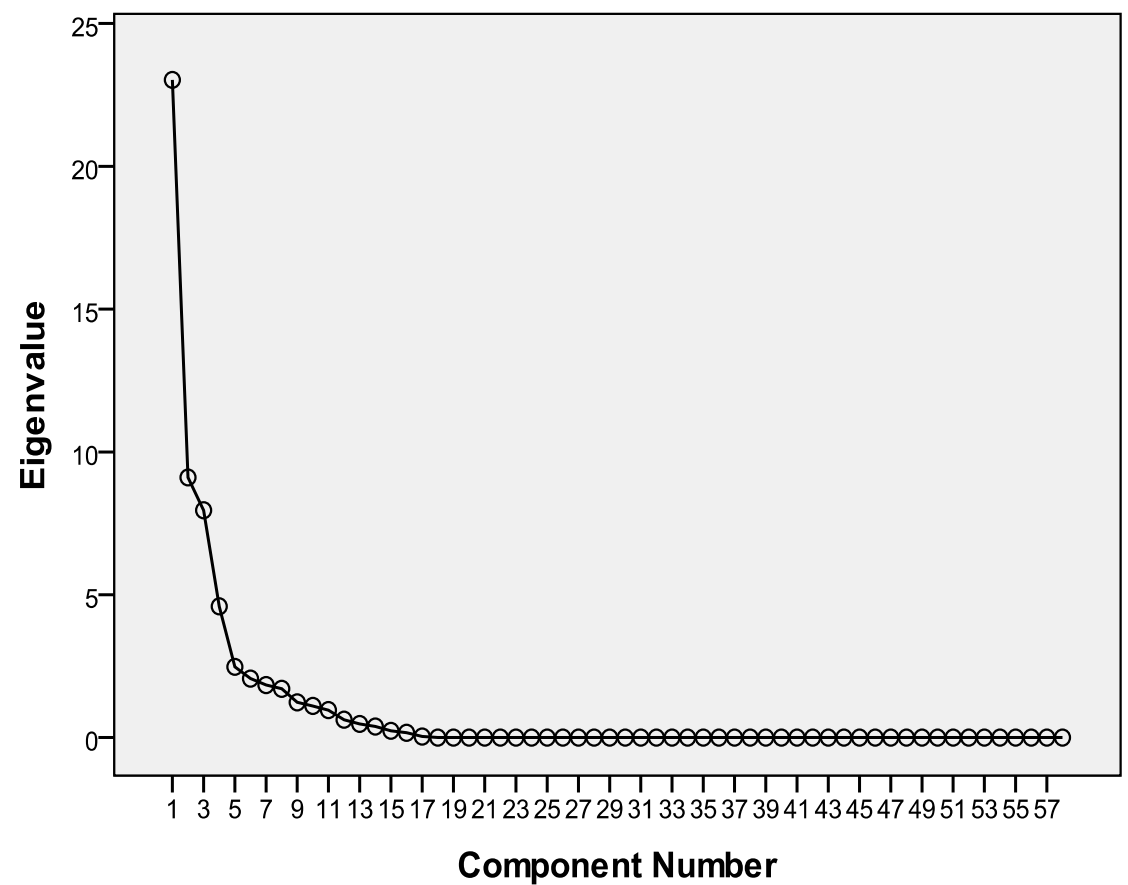

Fig. 1. Results of factor analysis: Scree Plot

Based on the number of the total variance explained (Table 5), these five factors can explain the $81.305 \%$ of the total variance. The Factors account for $33.631 \%, 18.869 \%, 12.353 \%, 8.309 \%$ and $8.142 \%$ of the total variance, respectively, for each factor.

Table 5

Results of factor analysis: Total Variance Explained

\begin{tabular}{|c|c|c|c|c|c|c|c|c|c|}
\hline \multirow{2}{*}{ Component } & \multicolumn{3}{|c|}{ Initial Eigen values } & \multicolumn{3}{|c|}{$\begin{array}{l}\text { Extraction Sums of Squared } \\
\text { Loadings }\end{array}$} & \multicolumn{3}{|c|}{$\begin{array}{c}\text { Rotation Sums of Squared } \\
\text { Loadings }\end{array}$} \\
\hline & Total & $\begin{array}{c}\% \text { of } \\
\text { Variance }\end{array}$ & $\begin{array}{c}\text { Cumulative } \\
\%\end{array}$ & Total & $\begin{array}{c}\% \text { of } \\
\text { Variance }\end{array}$ & $\begin{array}{c}\text { Cumulative } \\
\%\end{array}$ & Total & $\begin{array}{c}\% \text { of } \\
\text { Variance }\end{array}$ & $\begin{array}{c}\text { Cumulative } \\
\%\end{array}$ \\
\hline 1 & 23.025 & 39.698 & 39.698 & 23.025 & 39.698 & 39.698 & 19.506 & 33.631 & 33.631 \\
\hline 2 & 9.106 & 15.700 & 55.398 & 9.106 & 15.700 & 55.398 & 10.944 & 18.869 & 52.500 \\
\hline 3 & 7.957 & 13.720 & 69.117 & 7.957 & 13.720 & 69.117 & 7.165 & 12.353 & 64.853 \\
\hline 4 & 4.594 & 7.920 & 77.037 & 4.594 & 7.920 & 77.037 & 4.819 & 8.309 & 73.162 \\
\hline 5 & 2.475 & 4.267 & 81.305 & 2.475 & 4.267 & 81.305 & 4.723 & 8.142 & 81.305 \\
\hline
\end{tabular}

Table 6 shows the Rotated Component Matrix. The factor loading of each measurement item (shown in table 7) has been extracted from this matrix. 
Table 6

Results of factor analysis: Rotated Component Matrix

\begin{tabular}{|c|c|c|c|c|c|}
\hline \multirow{2}{*}{ Measurement Items } & \multicolumn{5}{|c|}{ Component } \\
\hline & 1 & 2 & 3 & 4 & 5 \\
\hline $\mathrm{x}_{1}$ Faithful employees & -.009 & -.254 & .964 & -.163 & .271 \\
\hline $\mathrm{x}_{2}$ Corporate Philanthropy & .107 & .037 & .011 & -.374 & .971 \\
\hline $\mathrm{x}_{3}$ Promoting Ethics & .192 & .969 & -.192 & -.019 & -.270 \\
\hline $\mathrm{x}_{4}$ Servant leadership & .983 & -.233 & -.006 & .065 & .115 \\
\hline $\mathrm{x}_{5}$ High quality relationship with employees & .839 & .306 & -.067 & .119 & .416 \\
\hline $\begin{array}{l}\text { Employee's readiness from the point of view of individual characteristics, motives, internal } \\
\mathrm{x}_{6} \text { tendency,... }\end{array}$ & .177 & .177 & .984 & -.347 & .289 \\
\hline $\mathrm{x}_{7}$ Employees as competitive advantages for organization & .192 & .819 & -.192 & .416. & -.270 \\
\hline $\mathrm{x}_{8}$ Considering virtuousness in organization's mission statement & .564 & .373 & -.172 & .567 & -.266 \\
\hline $\mathrm{x}_{9}$ Respect the social laws & .192 & -.270 & -.192 & -.019 & .756 \\
\hline $\mathrm{x}_{10}$ Not only concentrating on profit maximization & -.364 & .873 & -.172 & -.044 & .564 \\
\hline $\begin{array}{l}\text { Honor commitments to customers, teammates, communities, owners, suppliers and partners } \\
\mathrm{x}_{11} \text { (Keep promises and contracts) }\end{array}$ & .902 & .506 & -.192 & -.019 & -.270 \\
\hline $\mathrm{x}_{12}$ Going beyond ethics & .504 & .976 & .022 & -.192 & .283 \\
\hline $\mathrm{x}_{13}$ Avoiding harming others & .268 & -.297 & .407 & .043 & .789 \\
\hline $\mathrm{x}_{14}$ Spiritual leadership & .906 & .479 & -.124 & .023 & -.159 \\
\hline $\mathrm{x}_{15}$ Respecting the rights of others & .328 & .506 & -.154 & .212 & .764 \\
\hline $\mathrm{x}_{16}$ Being fair & .864 & .373 & -.172 & -.044 & -.266 \\
\hline $\mathrm{x}_{17}$ Obeying the law & .664 & .373 & -.172 & -.044 & -.266 \\
\hline $\mathrm{x}_{18}$ Respect the social values & .102 & .210 & .027 & .224 & .720 \\
\hline $\mathrm{x}_{19}$ Allotting a special budget to help the homeless find job and housing & -.152 & .044 & .512 & -.463 & .727 \\
\hline $\mathrm{x}_{20}$ Considering virtuousness in organization's mission statement as an end not as means & -.233 & -.006 & .153 & .865 & .115 \\
\hline $\mathrm{x}_{21}$ A high level of honesty and integrity at every organizational level (Not to cheat or tell lie) & .007 & .917 & .041 & 650 & .021 \\
\hline $\mathrm{x}_{22}$ Interpersonal relationships characterized by caring and compassion & .404 & .476 & .892 & -.192 & .283 \\
\hline $\mathrm{x}_{23}$ Hiring the Disabled & .272 & -.025 & -.110 & -.044 & .972 \\
\hline $\mathrm{x}_{24}$ Considering virtues in the culture of community & .124 & .373 & -.172 & -.044 & .864 \\
\hline $\mathrm{x}_{25}$ Employees perception of virtuousness in organization & .372 & -.025 & .710 & -.044 & -.185 \\
\hline $\mathrm{x}_{26}$ Respect and caring for Employees & .739 & -.011 & .162 & .445 & .354 \\
\hline $\mathrm{x}_{27}$ Matching managers conduct and words & .764 & -.242 & .267 & -.176 & -.464 \\
\hline $\mathrm{x}_{28}$ Existence of ethical standards for employee's and manager's behavior & .545 & .845 & .484 & -.004 & -.074 \\
\hline $\mathrm{x}_{29}$ Existence of transparency in organization (Shared information) & -.089 & .623 & .140 & .349 & .293 \\
\hline $\mathrm{x}_{30}$ Strive for excellence & .268 & .497 & .307 & .043 & .089 \\
\hline $\mathrm{x}_{31}$ Organizational citizenship behaviors & .498 & -.116 & .778 & .111 & -.139 \\
\hline $\mathrm{x}_{32}$ Indirect training through storytelling approach & .604 & -.033 & .048 & .419 & .241 \\
\hline $\mathrm{x}_{33}$ Reciprocal relationship and respect between managers and employees & -.204 & .776 & .022 & .192 & .283 \\
\hline $\mathrm{x}_{34}$ Human resource diversity at workplace & .102 & .310 & .027 & .224 & .820 \\
\hline $\mathrm{x}_{35}$ Help those in need & -.199 & -.084 & .127 & -.117 & .878 \\
\hline $\mathrm{x}_{36}$ Considering virtues in organizational policies and processes & -.377 & .384 & .417 & .534 & .179 \\
\hline $\mathrm{x}_{37}$ Concerning about the Environment and the community & -.204 & .476 & .022 & .192 & .783 \\
\hline $\mathrm{x}_{38}$ Optimal use of environmental resources & .172 & -.025 & -.110 & -.044 & .586 \\
\hline $\mathrm{x}_{39}$ Concerning about the Local suppliers & .164 & .373 & -.172 & -.044 & .566 \\
\hline $\mathrm{x}_{40}$ Paying attention to employee's development more than their training & .295 & 676 & -.116 & -.074 & -.008 \\
\hline $\mathrm{x}_{41}$ Considering employee's competencies & -.174 & .637 & .011 & .107 & .163 \\
\hline $\mathrm{x}_{42}$ Penetrating virtues in employee's feelings, thinking and actions & .297 & -.103 & 678 & .177 & .356 \\
\hline $\mathrm{x}_{43}$ Responsible leadership & .533 & -.006 & .253 & .065 & .115 \\
\hline $\mathrm{x}_{44}$ Diversity in the Workplace & .097 & -.103 & .178 & 677 & .356 \\
\hline $\mathrm{x}_{45}$ Behaving in a socially responsible and environmentally sensitive manner & .228 & .125 & -.056 & .178 & .778 \\
\hline $\mathrm{x}_{46}$ Managers support in all affairs especially in difficult situations and crises & .496 & .216 & -.008 & .268 & -.179 \\
\hline $\mathrm{x}_{47}$ Employee's stability in difficulties and crises & -.104 & .276 & .422 & .192 & .283 \\
\hline $\mathrm{x}_{48}$ Providing employees with an opportunity to grow and learn & .104 & .176 & .452 & .192 & .283 \\
\hline $\mathrm{x}_{49}$ An optimistic perspective toward challenges, difficulties, and opportunities & .474 & .037 & .011 & .107 & .163 \\
\hline $\mathrm{x}_{50}$ Employee's self-control & -.004 & .076 & .322 & .192 & -.283 \\
\hline $\mathrm{x}_{51}$ Empowering employees & .388 & .073 & -.015 & .099 & .279 \\
\hline $\mathrm{x}_{52}$ Paying attention to thinking and knowledge acquisition & -.027 & .354 & .102 & -.052 & .034 \\
\hline $\mathrm{x}_{53}$ Decreasing the hierarchy & .102 & .110 & .027 & .424 & .320 \\
\hline $\begin{array}{l}\text { The combination of high standards of performance with a culture of forgiveness and learning } \\
\text { from mistakes }\end{array}$ & .102 & .510 & .027 & .224 & .320 \\
\hline $\mathrm{x}_{55}$ Vesting authority to employees along with supporting from managers & .336 & .097 & .021 & .546 & .178 \\
\hline $\mathrm{x}_{56}$ Down to up hierarchy & .006 & .426 & .119 & .500 & .278 \\
\hline $\mathrm{x}_{57}$ Taking care of customers (Customer Satisfaction) & .336 & .466 & .062 & .320 & .090 \\
\hline $\mathrm{x}_{58}$ Courageous employees & .196 & .216 & .548 & .168 & -.179 \\
\hline
\end{tabular}

Extraction Method: Principal Component Analysis.

Rotation Method: Varimax with Kaiser Normalization.

Rotation converged in 8 iterations. 


\section{Table 7}

Results of factor analysis: Factor Loading of Measurement Items

\begin{tabular}{|c|c|c|c|c|c|c|}
\hline \multirow{2}{*}{\multicolumn{2}{|c|}{ Measurement Items }} & \multicolumn{5}{|c|}{ Component } \\
\hline & & 1 & 2 & 3 & 4 & 5 \\
\hline $\mathrm{x}_{4}$ & Servant leadership & $.983^{\mathrm{a}}$ & & & & \\
\hline $\mathrm{x}_{5}$ & High quality relationship with employees & .839 & & & & \\
\hline $\mathrm{x}_{11}$ & $\begin{array}{l}\text { Honor commitments to customers, teammates, communities, owners, } \\
\text { suppliers and partners (Keep promises and contracts) }\end{array}$ & .902 & & & & \\
\hline $\mathrm{x}_{14}$ & Spiritual leadership & .906 & & & & \\
\hline $\mathrm{x}_{16}$ & Being fair & .864 & & & & \\
\hline $\mathrm{x}_{17}$ & Obeying the law & 664 & & & & \\
\hline $\mathrm{x}_{26}$ & Respect and caring for Employees & .739 & & & & \\
\hline $\mathrm{x}_{27}$ & Matching managers conduct and words & .764 & & & & \\
\hline $\mathrm{x}_{32}$ & Indirect training through storytelling approach & .604 & & & & \\
\hline $\mathrm{x}_{43}$ & Responsible leadership & .533 & & & & \\
\hline $\mathrm{x}_{46}$ & Managers support in all affairs especially in difficult situations and crises & .496 & & & & \\
\hline $\mathrm{x}_{49}$ & An optimistic perspective toward challenges, difficulties, and opportunities & .474 & & & & \\
\hline $\mathrm{x}_{51}$ & Empowering employees & .388 & & & & \\
\hline $\mathrm{x}_{3}$ & Promoting Ethics & & 969 & & & \\
\hline $\mathrm{x}_{7}$ & Employees as competitive advantages for organization & & .819 & & & \\
\hline $\mathrm{x}_{10}$ & Not only concentrating on profit maximization & & .873 & & & \\
\hline $\mathrm{x}_{12}$ & Going beyond ethics & & .976 & & & \\
\hline $\mathrm{x}_{21}$ & $\begin{array}{l}\text { A high level of honesty and integrity at every organizational level (Not to } \\
\text { cheat or tell lie) }\end{array}$ & & .917 & & & \\
\hline $\mathrm{X}_{28}$ & Existence of ethical standards for employee's and manager's behavior & & .845 & & & \\
\hline $\mathrm{x}_{29}$ & Existence of transparency in organization (Shared information) & & 623 & & & \\
\hline $\mathrm{x}_{30}$ & Strive for excellence & & .497 & & & \\
\hline $\mathrm{x}_{33}$ & Reciprocal relationship and respect between managers and employees & & .776 & & & \\
\hline $\mathrm{x}_{40}$ & Paying attention to employee's development more than their training & & 676 & & & \\
\hline $\mathrm{x}_{41}$ & Considering employee's competencies & & 637 & & & \\
\hline $\mathrm{x}_{52}$ & Paying attention to thinking and knowledge acquisition & & .354 & & & \\
\hline $\mathrm{x}_{54}$ & $\begin{array}{l}\text { The combination of high standards of performance with a culture of } \\
\text { forgiveness and learning from mistakes }\end{array}$ & & .510 & & & \\
\hline $\mathrm{x}_{57}$ & Taking care of customers (Customer Satisfaction) & & .466 & & & \\
\hline $\mathrm{x}_{1}$ & Faithful employees & & & .964 & & \\
\hline $\mathrm{x}_{6}$ & $\begin{array}{l}\text { Employee's readiness from the point of view of individual characteristics, } \\
\text { motives, internal tendency,... }\end{array}$ & & & .984 & & \\
\hline $\mathrm{x}_{22}$ & Interpersonal relationships characterized by caring and compassion & & & .892 & & \\
\hline $\mathrm{x}_{25}$ & Employees perception of virtuousness in organization & & & .710 & & \\
\hline $\mathrm{x}_{31}$ & Organizational citizenship behaviors & & & .778 & & \\
\hline $\mathrm{x}_{42}$ & Penetrating virtues in employee's feelings, thinking and actions & & & .678 & & \\
\hline $\mathrm{x}_{44}$ & Diversity in the Workplace & & & .778 & & \\
\hline $\mathrm{x}_{47}$ & Employee's stability in difficulties and crises & & & .422 & & \\
\hline $\mathrm{x}_{50}$ & Employee's self-control & & & .322 & & \\
\hline $\mathrm{x}_{58}$ & Courageous employees & & & .548 & & \\
\hline $\mathrm{x}_{44}$ & Diversity in the Workplace & & & .677 & & \\
\hline $\mathrm{x}_{8}$ & Considering virtuousness in organization's mission statement & & & & .567 & \\
\hline $\mathrm{x}_{20}$ & $\begin{array}{l}\text { Considering virtuousness in organization's mission statement as an end not } \\
\text { as a means }\end{array}$ & & & & .865 & \\
\hline $\mathrm{x}_{36}$ & Considering virtues in organizational policies and processes & & & & .534 & \\
\hline $\mathrm{x}_{53}$ & Decreasing the hierarchy & & & & .424 & \\
\hline $\mathrm{x}_{55}$ & Vesting authority to employees along with supporting from managers & & & & .546 & \\
\hline $\mathrm{x}_{56}$ & Down to up hierarchy & & & & .500 & \\
\hline $\mathrm{x}_{2}$ & Corporate Philanthropy & & & & & .971 \\
\hline $\mathrm{x}_{9}$ & Respect the social laws & & & & & .756 \\
\hline $\mathrm{x}_{13}$ & Avoiding harming others & & & & & .789 \\
\hline $\mathrm{x}_{15}$ & Respecting the rights of others & & & & & .764 \\
\hline $\mathrm{x}_{18}$ & Respect the social values & & & & & .720 \\
\hline $\mathrm{x}_{19}$ & Allotting a special budget to help the homeless find job and housing & & & & & .727 \\
\hline $\mathrm{x}_{23}$ & Hiring the Disabled & & & & & .972 \\
\hline $\mathrm{x}_{24}$ & Considering virtues in the culture of community & & & & & .864 \\
\hline $\mathrm{x}_{34}$ & Human resource diversity at workplace & & & & & .820 \\
\hline $\mathrm{x}_{35}$ & Help those in need & & & & & .878 \\
\hline $\mathrm{x}_{37}$ & Concerning about the Environment and the community & & & & & .783 \\
\hline $\mathrm{x}_{38}$ & Optimal use of environmental resources & & & & & .586 \\
\hline $\mathrm{x}_{39}$ & Concerning about the Local suppliers & & & & & .566 \\
\hline $\mathrm{x}_{45}$ & Behaving in a socially responsible and environmentally sensitive manner & & & & & .778 \\
\hline
\end{tabular}

a. Factor Loading 


\section{Discussion}

The factor analysis empirically grouped the scale items of virtuous organization into five factors (principal components). The five factors can be labeled as follows:

The first factor can be labeled as "Leadership" and consists of measurement items $\mathrm{x}_{4}, \mathrm{x}_{5}, \mathrm{x}_{11}, \mathrm{x}_{14}, \mathrm{x}_{16}$, $\mathrm{x}_{17}, \mathrm{x}_{26}, \mathrm{x}_{27}, \mathrm{x}_{32}, \mathrm{x}_{43}, \mathrm{x}_{46}, \mathrm{x}_{49}$ and $\mathrm{x}_{51}$. This factor is accounted for $33.631 \%$ of the total variance and it is ranked first (the most important) with an importance index of 79.00 (according to Table 10). Leaders play critical role in providing a moral framework for organizational members and in shaping the virtuous culture (Neubert et al., 2009). They can communicate and perpetuate either virtue or vice through their interpersonal relationships with their subordinates and their behaviors (Flynn, 2008). Managers who engage in ethical leadership behavior act as virtuous agents in promoting an ethical climate (Flynn, 2008). The influence of ethical leadership may also be considered to be virtuous in that it can extend beyond promoting an ethical climate to influence organizational members' attitudes toward everyday work (i.e., job satisfaction) and attachments to the organization (i.e., affective organizational commitment). From a virtue perspective, behavior that contributes to "the flourishing of all members of a community" is virtuous (Neubert et al., 2009). Leaders should consider some points for effective leadership (Lawler, 2004):

- Lead People Right: The leadership at any level in a particular firm maintains an impact on both individual and organizational effectiveness. The type of relationships where people develop with organizations including how motivated they are, how long they stay, and how they treat customers and other employees are determined.

- Developing a Leadership Brand: A crystal clear leadership style is a powerful factor in absorbing, retaining, and motivating employees, properly. A positive leadership brand, which permeates the organization can also serve as a touchstone for all current employees who are managers or desire to be managers, guiding them toward organization's "true north" with respect to the leadership behaviors and skills expected of them.

- Build Leadership Capability: Given the role it plays in determining success, leadership capability is something organizations require to construct a basis.

- Focus on the Competitive Environment: Effective leaders adjust their leadership attitude to the economic times and they must remain true to the basic leadership brand of their organization.

The second factor can be labeled as "Organizational Culture" and consists of measurement items $\mathrm{x}_{3}$, $\mathrm{x}_{7}, \mathrm{x}_{10}, \mathrm{x}_{12}, \mathrm{x}_{21}, \mathrm{x}_{28}, \mathrm{x}_{29}, \mathrm{x}_{30}, \mathrm{x}_{33}, \mathrm{x}_{40}, \mathrm{x}_{41}, \mathrm{x}_{52}, \mathrm{x}_{54}$ and $\mathrm{x}_{57}$. This factor is accounted for $18.869 \%$ of the total variance and it is ranked second with a relative importance index of 73.94 (according to Table 10). An organizational culture based on ethics, transparency, honesty and reciprocal relationship and respect between managers and employees can help achieve organizational virtuousness (Whetstone, 2005).

The third factor can be labeled as "Human Resource" and consists of measurement items $\mathrm{x}_{1}, \mathrm{x}_{6}, \mathrm{x}_{22}$, $\mathrm{x}_{25}, \mathrm{x}_{31}, \mathrm{x}_{42}, \mathrm{x}_{44}, \mathrm{x}_{47}, \mathrm{x}_{50}, \mathrm{x}_{58}$ and $\mathrm{x}_{44}$. This factor is accounted for $12.353 \%$ of the total variance and it is ranked third with an importance index of 72.81 (according to Table 10). A virtuous organization includes people who provide a high quality relationship with its employees since a virtuous organization's competitive advantage is its people. On the other hand, moving towards virtuousness requires different things such as employee's self-control, faithfulness, organizational citizenship behaviors, perception of virtuousness perception of virtuousness, readiness, Interpersonal relationships characterized by caring and compassion, etc. The forth factor is labeled as "Structure and Processes" and consists of measurement items $\mathrm{x}_{8}, \mathrm{x}_{20}, \mathrm{x}_{36}, \mathrm{x}_{53}, \mathrm{x}_{55}$ and $\mathrm{x}_{56}$. This factor is accounted for $8.309 \%$ of the total variance and it is ranked fifth with an importance index of 68.38 (according to Table 10). Organizational virtuousness may be fostered by the organizational policies, processes, practices, and structure (Cameron, 2010; Dutton \& Sonenshein, 2007). 
The fifth factor can be labeled as "Care for Community" and consists of measurement items $\mathrm{x}_{2}, \mathrm{x}_{9}$, $\mathrm{x}_{13}, \mathrm{x}_{15}, \mathrm{x}_{18}, \mathrm{x}_{19}, \mathrm{x}_{23}, \mathrm{x}_{24}, \mathrm{x}_{34}, \mathrm{x}_{35}, \mathrm{x}_{37}, \mathrm{x}_{38}, \mathrm{x}_{39}$ and $\mathrm{x}_{45}$. This factor is accounted for $8.142 \%$ of the total variance and it is ranked forth with an importance index of 65.33 (according to Table 10). A virtuous firm should establish and maintain strong ties with the local community in which it conducts business. It should hire employees from the local community and do business with local companies. After all, many of a firm's customers will come from the surrounding areas. Additionally, a virtuous firm should be concerned about our planet. Planet Earth is all we have and we should take care of it (Friedman \& Friedman, 2009). Reliability of the five extracted factors was evaluated by Cronbach's alpha. Table 8 and 9 show the output of the reliability test. As can be seen, all Cronbach's alpha values are well above the limit of 0.70 and ensure the constructs' internal consistency and reliability (Ghosh \& Jintanapakanont, 2004).

\section{Table 8}

Case Processing Summary

\begin{tabular}{|c|c|c|c|}
\hline & & $\mathrm{N}$ & $\%$ \\
\hline \multirow[t]{3}{*}{ Cases } & Valid & 574 & 100.0 \\
\hline & Excluded $^{\mathrm{a}}$ & 0 & .0 \\
\hline & Total & 574 & 100.0 \\
\hline
\end{tabular}

a. Listwise deletion based on all variables in the procedure

\section{Table 9}

Reliability and Descriptive Statistics

\begin{tabular}{lcccccc}
\multicolumn{1}{c}{ Principal Factor } & $\mathrm{N}$ & Mean & $\begin{array}{c}\text { Std. } \\
\text { Deviation }\end{array}$ & $\begin{array}{c}\text { Cronbach's } \\
\text { Alpha }\end{array}$ & $\begin{array}{c}\text { Cronbach's Alpha Based } \\
\text { on Standardized Items }\end{array}$ & No. of Items \\
\hline Leadership & 574 & 4.8800 & .32537 & .782 & .815 & .798 \\
Organizational Culture & 574 & 4.2200 & .75699 & .791 & .795 & 14 \\
Human Resource & 574 & 4.7574 & .43918 & .739 & .749 & 11 \\
Structure and Processes & 574 & 3.7000 & .67166 & .767 & .903 & 6 \\
Care for Community & 574 & 4.7800 & .41477 & .901 & .956 & 14 \\
\hline Total & 574 & ---- & ---- & .949 & 58 \\
\hline
\end{tabular}

In this section, we rank the principal factors extracted from factor analysis. For this type of data, the mean and standard deviation of each factor are not suitable to determine the overall ranking because they do not reflect any relationship among the factors. Instead, the weighted average for each factor was calculated and then it is divided by the upper scale of the measurement. Therefore, the level of importance of the principal factors was calculated using the following formula (Ghosh \& Jintanapakanont, 2004):

Importance index $=\sum(a X) * \frac{100}{5}$,

where $a$ is the constant, which expresses the weighting given to each response, ranging from 1 (not important) to 5 (extremely important); and $X=n / N$, where $n$ is the frequency of the responses; and $N$ is the total number of responses. Each rank in Table 10 presents the degree of importance assigned to principal factors of a virtuous organization, extracted from factor analysis.

\section{Table 10}

Importance index of each principal factor

\begin{tabular}{lcc}
\hline \multicolumn{1}{c}{ Principal Factor } & Importance Index & Rank \\
\hline Leadership & 79.00 & 1 \\
Organizational Culture & 73.94 & 2 \\
Human Resource & 72.81 & 3 \\
Care for Community & 68.38 & 4 \\
Structure and Processes & 65.33 & 5 \\
\hline
\end{tabular}




\section{Conclusion}

In this study, we presented an empirical study to detect the relative importance of various drivers of a virtuous organization and conducted an exploratory factor analysis to extract the principal factors of virtuous organization to put virtues into practice. The results of factor analysis demonstrated that a five-factor measurement model including leadership, organizational culture, human resource, structure and processes and care for community fits the data acceptably.

Maximizing profits while ignoring the needs of society may work in the short run but it may create unfavorable events for both society and business in the long run. In addition, while many of the ideas recommended in this paper may not only be costless to an organization but even produce additional profits in the long run, that is not the only reason to consider them. After all, "for the virtuous organization, virtue is indeed its own reward".

\section{References}

Ahmed, P.K., \& Machold, S. (2004). The Quality and Ethics connection: Toward virtuous organization. Total Quality Management, 15(4), 527-545.

Barge, J., Kevin, \& Oliver, C. (2003). Working with appreciation in managerial practice. Academy of Management Review.

Beauchamp, T. L., \& Childress, J. F. (1994). Principles of Biomedical Ethics. New York: Oxford University Press.

Bright, D. S., Cameron, K. S., \& Caza, A. (2006). The amplifying and buffering effects of virtuousness in downsized organizations. Journal of Business Ethics, 64, 249-269.

Cameron, K. (2003). Organizational virtuousness and performance, In Positive Organizational Scholarship. KS Cameron, JE Dutton and RE Quinn (eds.), San Francisco: Berrett-Koehler.

Cameron, K. S. (2010). Five keys to flourishing in trying times. Leader to Leader, 55, 45-51.

Cameron, K. S. (2011). Responsible leadership as virtuous leadership. Journal of Business Ethics, 98, 25-35.

Cameron, K. S., Bright, D., \& Caza, A. (2004). Exploring The relationships Between organizational virtuousness and performance. American Beharioral scientist, 47, 766-790.

Caza, A., \& Carroll, B. (2012). Critical studies and positive organizational scholarship. In K. S. Cameron \& G. M. Spreitzer (Eds.), Oxford handbook of positive organizational scholarship. New York: Oxford University Press.

Chappell, T. (1993). The soul of a business: managing for profit and the common good. New York, Bantam

Collins, D. (2000). Virtuous Individuals, Organizations and political Economy: A new Age theological Alternative to capitalism. Journal of Business Ethics, 26, 319-340.

Comte-Sponville, A. (2001). A small treatise of the great virtues. New York: Metropolitan Books.

Cooper, T. L. (1987). Hierarchy, virtue and the practice of public Administration: A perspective for Normative Ethics. Public Administration Review, July/August, 320-328

Dutton, J. E., \& Sonenshein, S. (2007). Positive organizational scholarship. In S. Lopez \& A. Beauchamps (Eds.), Encyclopedia of positive psychology. Malden, MA: Blackwell Publishing.

Dutton, J. E., Frost, P. J., Worline, M. C., Lilius, J. M., \& Kanov, J. M. (2002). Leading in times of trauma. Harvard Business Review, January, 54-61.

Flynn, G. (2008). The Virtuous Manager: A Vision for Leadership in Business. Journal of Business Ethics, 78, 359-372.

Friedman, H. H., Friedman, I. W., \& Kass-shraibman, F. (2008). Ethical Imperatives of CEO's: Creating the virtuous corporation. Journal oF Business systems Governance \& Ethics, 3(4), 31-41.

Friedman, H. H., \& Friedman, L. W. (2009). How virtuous is your firm? A checklist. Electronic Journal of Business Ethics and organization studies, 14(1), 14-20. 
Ghosh, S., \& Jintanapakanont, J. (2004). Identifying and assessing the critical risk factors in an underground rail project in Thailand: a factor analysis approach. International Journal of Project Management 22, 633-643.

Grimley, B. (2008). Costco CEO: Ethics Imperative. Kitsap Sum.

Hannah, S. T. \& Avolio, B. J. (2011). Leader Character, ethos and Virtue: Individual and Collective consideration. The leadership Quarterly, 22, 989-994.

Ip, Po-keung (2002). the weizhi group of xian: A Chinese virtuous corporation. Journal of Business Ethics, 35, 15-26.

Lawler, E. E. (2004). Leading a virtuous - spiral organization. Leader to Leader, 32, spring.

Maak, T., \& Pless, N. M. (2006). Responsible leadership in a stakeholder society-a relational perspective. Journal of Business Ethics, 66, 99-115.

Magill, R. G., \& Prybil, L. (2001). Guidelines for organizational Ethics: The goal should be virtuous organizations with a Community Covenant. Health Progress, (july-August 2001), 12-14.

Manz, C. C., Cameron, K. S., Manz, K. P., Marx, R. D., \& Neal, J. (2008). The Virtuous Organization: Insights from Some of the World Leading Management Thinkers. World Scientific Publishing Company.

Nepean, W. (2007). Virtuous Firms Perform Better: An Empirical Investigation of Organizational Virtues and Performance. Business Post Comment.

Neubert, M. J., Carlson, D., Kacmar, K. M., Roberts, J. A., \& Chonko, L. B. (2009). the virtuous influence of ethical leadership behavior: Eridence from the field. Journal of Business Ethics, 90, 157-170.

Paine, L. S. (2003). Value shift. McGraw-Hill, New York.

Peterson, C. (2003). Classification of positive traits in youth, Promoting Positive Child, Adolescent, and Family Development. RM Lerner, F Jacobs and D Wertlieb (eds.), 4, 227-255.

Pless, N. M. (2007). Understanding responsible leadership: Role identity and motivational drivers. Journal of Business Ethics, 74, 437-456.

Rego, A., Ribeiro, N., Cunha, M., \& Jesuino, J.C. (2011). How Happiness Mediates the Organizational Virtuousness and Effective Commitment Relation Ship. Journal of Business Research, 64, 524-532.

Saylor, F. (2005). Business benefit from a low-key spirituality. Science and Technology News, Retrieved from http://www.stnews.org/rlr-494.html

Schudt, K. (2000). Taming the Corporate Monster: An Aristotelian Approach to Corporate Virtue. Business Ethics Quarterly, 10(3), 711-723.

Seligman, M. E. P., \& Csikszentmihalyi, M. (2000). Positive psychology: an introduction. American Psychologist 55, 5-14.

Snyder, C. R., \& Lopez, S. J. (2002). Handbook of Positive Psychology. New York, Oxford University Press.

Sosik, J. J., Gentry, W. A., \& Chun, J.U.K. (2011). The value of virtue in the upper echelons: A multisource examination of executive character Strengths and performance. The Leadership Quarterly, 1-16.

Trevino, L., \& Weaver, G. (2003). Managing Ethics in Business Organizations: Social Scientific Perspectives. Stanford, CA: Stanford University Press.

Wright, T. A., \& Goodstein, J. (2007). Character is not dead in management research: A review of individual character and organization-level virtue. Journal of Management, 33, 928-948.

Whetstone, J. T. (2005). A Framework for organizational virtue: The interrelationship of mission, culture and leadership. Business Ethics: A European Review 14(4), 367- 378 